\title{
Contract Farming as Part of a Multi-Instrument Inclusive Business Structure: A Theoretical Analysis
}

\author{
W.O. Chamberlain a, ${ }^{*}$ and W. Anseeuw ${ }^{b}$
}

apostgraduate School of Agriculture and Rural Development, University of Pretoria;

$\mathrm{b}_{\mathrm{CIRAD}}$ and International Land Coalition

*Correspondence to: wytske.chamberlain@up.ac.za

\begin{abstract}
Contract farming (CF) agreements are presently being restructured to form part of more complex Inclusive Business (IB) set-ups. Additional instruments, alongside CF, are implemented to overcome the challenges of $\mathrm{CF}$ and to adapt to the policy environment in which the different stakeholders operate. This paper develops a theoretical framework that gives insight into how these complex entities are structured and operate in a developing country context. This theoretical analysis takes a holistic approach by adopting elements of existing theories to form a new critical research paradigm: i) Resource Dependence Theory to incorporate the wider operating environment in which the two cases operate, ii) Transaction Cost Economics to explain the internal efficiency of the different models, and iii) Agency Theory to account for the safeguard mechanisms. This new framework is then tested on two complex IBs that aim to integrate smallholder farmers into the commercial value chain, but which have each implemented a different institutional set-up developed around CF arrangements. It finds that a high dependence by the offtaker in the first case study stimulates a higher level of commitment and investment by this stakeholder in the contract arrangement. In turn, this increases the asset specificity aspect, which then requires safeguards to ensure the smallholders adhere to the contractual agreement. A higher dependency in this particular study also resulted in a higher number of smallholders being engaged in the contract, requiring mechanisms to efficiently monitor and coordinate them.
\end{abstract}

Keywords: Inclusive business, contract farming, resource dependence theory, transaction cost economics, agency theory

JEL Classification: L140, O130, Q130

\section{Introduction}

A large body of literature exists on contract farming (CF), focusing on aspects such as the contractual agreements (Allen and Lueck, 1992), the potential for smallholder farming in developing countries (Prowse, 2012; da Silva and Rankin, 2013), the impact of CF on these smallholders (Bellemare, 2012), and the challenges of CF (Eaton and Shepherd, 2001) as well as other thematics. Although most of these publications look at CF as a single tool for farmers to become integrated in the commercial value chain, some authors have highlighted the option for CF to be supported by additional instruments, mainly in order to overcome known challenges (e.g. Glover, 1987; Prowse, 2007; da Silva and Rankin, 2013). In South Africa various examples of set-ups are found that go beyond traditional CF arrangements, incorporating CF in a complex Inclusive Business (IB) set-up (Chamberlain and Anseeuw, 2015). These complex Inclusive Businesses (IB) can take many forms, for example by including different instruments (e.g. collective organisation, equity, mentorship and/or lease) 
in varying set-ups, all structured around a traditional supply contract. Little is yet understood about the drivers that lead to these complex contracting arrangements, or about the way they are structured and operate. Whereas CF has been explained from a Transaction Cost Economics approach (Kirsten and Sartorius, 2002; Bijman, 2008) or by Agency Theory (e.g. Clemente and da Silva Júnior, 2013; Vavra, 2009), the current trend of utilising multidimensional relationships beyond a single supply contract requires revisiting and complementing these theoretical approaches.

This paper aims to gain insight into how different theories contribute to the institutional setup of IBs that have incorporated CF. Using aspects of Resource Dependence Theory (RDT), Transaction Cost Economics (TCE) and Agency Theory (AT), the paper explores why and how two contracting arrangements, which have similar objectives, diverge in the institutional set-up implemented. Thus, two new elements for the existing literature on CF are brought to the fore. Firstly, this paper looks at CF set-ups that operate in conjunction with other instruments in complex IBs. It analyses the interaction between these instruments rather than the separate instruments by themselves. Previous work is lacking in the theoretical analysis of these complex entities. Secondly, the theoretical approach is of a holistic nature. By applying the three theories, the institutional set-ups are not seen in isolation, rather a broader view is attained which covers aspects of the internal efficiency (TCE), the relationship between the partners (AT), and the relationship with the operating environment (RDT). Whereas CF in the framework of the individual theories has been described in numerous publications (e.g. Bijman, 2008; Kirsten and Sartorius, 2002), this work presents an overall framework in which the three theories, TCE, AT and RDT, interact. It argues that the three theories conjoin to determine the set-up of the partnership eventually constructed by the stakeholders.

Although the paper is theoretical in nature, it is based on empirical research. The analysis contains two cases involving emerging farmers who are supported by an intermediary NGO which mentors the smallholders within the framework of a supply contract. Information was obtained through semi-structured interviews with all stakeholders, including representatives of the offtaker, the implementing agent (mentor) and a representative sample of ten smallholders in case A, and 27 farmers in case B. Semi-structured interviews allowed for gaining an in-depth understanding of each of the stakeholder's insights, whilst maintaining a structure that covered the same central themes, which subsequently could be compared. Follow-up questions provided clear answers in cases of contradictory information received from the different respondents during the formal interviews. Data was further triangulated by the use of annual scorecards kept by the mentor detailing production data of the individual smallholders. Applying both quantitative and qualitative data, as well as including different stakeholders, increases the internal validity of the cases researched (Yin, 1984; Eisenhardt, 1989a).

Results from this paper rest on these two IBs. Generalisation of the findings requires further studies to ascertain the validity of the theoretical framework. Especially analysing IBs with different stakeholders, such as government, NGOs, and/or third party service providers, will test the developed framework more widely. Furthermore, IBs are developing into complex 
entities, which adapt over time (Chamberlain \& Anseeuw, Forthcoming). Thus, although theory can contribute to the understanding of an initial IB structure, it needs to be taken into account that institutional structures partly emerge from a series of ever changing relationships, opportunities and experiences, within the IB and in the wider operating environment.

The paper is built up of six sections. Section 2 presents a short overview of the existing literature on CF and how this instrument fits into a more complex IB structure. Section 3 presents the theoretical framework outlining the three theories in detail. The two case studies are described in section 4 . These sections set the scene for the theoretical rationalisation of the institutional set-ups in section 5, applying the theories outlined in the theoretical framework section. The paper rounds off with a conclusion (section 6).

\section{Contract farming as part of complex inclusive businesses}

CF has been promoted as an instrument to promote smallholder farmers' access to commercial markets, both domestically and globally (e.g. da Silva and Rankin, 2013). Although CF takes many forms such as the centralised and multipartite model (Eaton and Shepherd, 2001), the common idea in developing countries is that a commercial firm provides inputs to (resource-poor) farmers who agree up front to deliver their crops to this commercial offtaker. Control over the production process is usually shared between offtaker and farmer. Contracts typically specify items such as quantity, quality, time and price determination (Singh, 2002).

In a nutshell, ${ }^{1}$ for the commercial firm, the benefits lie mainly in the increased control over its inputs. The firm knows how much produce it can expect and when. Partial control over the production process also results in higher reliability in the standard of produce supplied (Bolwig, Gibbon and Jones, 2009; Guo, Jolly and Zhu, 2005). Short-term contracts allow for flexibility in quantity sourced, as firms can adjust the quantities sourced through contracts depending on their anticipated demand (Miyata, Minot and Hu, 2009). Own farming activities do not offer this flexibility owing to the high sunk costs that need to be recovered. Supply contracts prevent challenges related to own production, such as labour unrest (Clapp, 1988) or production risks (Watts, 1992). In addition CF, certainly in developing countries, can be seen as beneficial for the firm's social image as it is considered to be of developmental impact for the contracted smallholders (Baumann, 2000). Smallholder farmers, on the other hand, potentially benefit from access to markets, technology and inputs (Simmons, Winters and Patrick, 2005: Vellema, 2002). Through pre-determined price agreements, part of the price risk is reduced, although production risks remain (Dileep, Grover and Rai, 2002). Knowledge and technology provided by the firm can enable the smallholder to increase yields (Miyata et al., 2009). This knowledge can then be applied by the farmers to other crops, in addition to their contracted crops. Input supply by the offtaker firms serves to overcome financial constraints faced by the smallholders (Nagaraj et al., 2008).

\footnotetext{
${ }^{1}$ For more detailed descriptions and analyses of CF, see the extensive works of Eaton and Shepherd, 2001; Kirsten and Sartorius, 2002; da Silva, 2005; Bijman, 2008; Prowse, 2012.
} 
For both parties, challenges exist, particularly where contracts are incomplete or where lack of enforcement controls fail to prevent contract breach. As a result, side-selling and input diversion by the smallholders are often observed (Barrett et al., 2012; Saavedra, 2014). Firms encounter high transaction costs in managing and monitoring a large number of spatially dispersed farms (Kirsten and Sartorius, 2002). Farmers, on the other hand, face potentially monopolistic offtakers, often lack bargaining power, lose autonomy over their farming activities, and face the risk of becoming locked into a vicious circle of debt (Eaton and Shepherd, 2001).

In order to mitigate these issues and challenges, standard CF is combined with other instruments in the framework of complex IBs. As such, an IB is "a profit-oriented partnership between a commercial agribusiness and low-income communities or individuals, in which the low-income community or individual is integrated in the commercial agricultural supply chain as a supplier of land, produce or value-sharing employment with a particular aim to develop its beneficiaries."(Chamberlain and Anseeuw, 2016:2).

Although standard CF arrangements can be considered as an IB (e.g. Rösler et al. 2013), IB is - at least in the framework of this paper - understood as a combination of instruments, leading to a more complex set-up aimed at integrating smallholder farmers into commercial value-chains. As illustrated by Chamberlain and Anseeuw (forthcoming), these more complex institutional set-ups apply a combination of several to all of the five basic instruments: CF, often forming the basis of the partnership, together with collective organisation, equity, mentorship and/or lease. Previous publications have highlighted the heterogeneous character of $\mathrm{CF}$, in part due to the combination with these additional instruments (e.g. Simmons et al., 2005; Oya, 2012). The remainder of this section will briefly outline the existing literature on why CF is partnered with these instruments and how this impacts on the organisational structure.

Firstly, collective organisations - such as farmers' organisations - are promoted to reduce transaction costs incurred when working with a large number of contracted smallholders (Coulter et al., 1999; da Silva, 2005). In addition, a producer organisation can increase, through the joining of forces as well as increased produce volumes, the bargaining power of the smallholders, bringing about a more equal relationship between offtaker and farmer (Glover, 1987; Bijman, 2008). A last argument for contract agreements combined with a producer organisation is that it offers a channel for external organisations to provide support, for example to better prepare the farmers with regard to standards set by commercial markets (Prowse, 2007). Producer organisations, on the other hand, add complexity to an IB structure that builds on CF, as is pointed out by Glover (1987). Chamberlain and Anseeuw (forthcoming) illustrate the point that these organisations limit the smallholders' understanding of the contract and of the general working of the overall IB. In turn, this lack of understanding has a potential negative impact on the commitment of the smallholders. Although the presence of a producer organisation often seems to be a prerequisite for the commercial offtaker to engage with smallholder farmers, thus forming an essential condition to access the commercial value chain, the institutional set-up which combines CF with a 
collective organisation tends to lower the level of inclusiveness for the farmer, as compared with a direct supply agreement between firm and farm (Chamberlain and Anseeuw, Forthcoming)

Secondly, equity is applied as a strategy aimed to overcome the issue of side-selling. Providing equity in the offtaker to the contracted smallholders is expected to trigger a higher level of commitment of the smallholder to the contract agreement. Indeed, an increase in activity of the offtaker is likely to increase the overall performance of the offtaker, resulting in potential dividends being paid out to the smallholders. De Koning and de Steenhuijsen Piters (2009) describe several successful cases of smallholder farmers with shareholding in the offtaker. On the other hand, the equity tool is often little understood by the smallholders, thus not generating the anticipated commitment effect. This is amplified by the discrepancy between the short-term cash requirement of the majority of smallholders and the long-term business objectives of the offtaker, resulting in dividends not being proclaimed in the initial years of the undertaking (Chamberlain and Anseeuw, Forthcoming).

Thirdly, support by an external stakeholder, such as a government body or an NGO, essentially describes the multipartite model and the intermediary model identified by Eaton and Shepherd (2001). In the multipartite model, direct interaction exists between the agribusiness and the smallholder, but with additional responsibilities for a third party. The external party can play the role of identifying smallholders or providing support to, and capacity development of, the farmers (Eaton and Shepherd, 2001; Simmons, 2002; Strohm and Hoeffler, 2006). Multipartite CF can spread the risk over multiple stakeholders, especially in new ventures. It can also reduce the risk for investors through the provision of government funds or by NGO funding.

In the intermediary model, the agribusiness transfers the full implementation of the CF to a third party and does not create direct interaction with the smallholders. Particularly in cases where a large number of smallholders is involved or where the offtaker lacks agri-business expertise, the inclusion of a third party offers an economical solution for the offtaker (Strohm and Hoeffler, 2006). Nevertheless, the intervention of an independent intermediary often impedes coordination across the chain and farmer incentive (Bijman, 2008:4).

Fourthly, the role of land lease in CF has not received specific interest. Nevertheless, land tenure and ownership has been highlighted in the analysis of CF case studies. As such, Simmons et al. (2005) find that Indonesian smallholders with ownership of irrigated land were more likely to participate in CF agreements. This is confirmed by Bellemare (2012) in his study on CF in Madagascar. Lack of secure land tenure, in general, can form a challenge to the successful integration of smallholders, as the investor risks loss of its investment in the project if the smallholder becomes involved in land disputes with the land owner (Eaton and Shepherd, 2001). Communal land tenure, as opposed to freehold title deed, limits the expansion opportunities for smallholders, which consequently limits their benefits from CF (Levin, 1987). On the other hand, smallholders without secure tenure might be more inclined to enter into CF. Lack of collateral prevents them from obtaining loans, which can be compensated for by input provision on a CF arrangement (Simmons, 2002). In general, CF 
seems to be more viable in cases where smallholders have secure tenure of a moderate size, in areas with high potential for commercial farming. In effect, this potentially excludes the most marginal of smallholders from CF (e.g. Baumann, 2000; Simmons, 2002).

These instruments are generally assessed on an individual basis. Their interactions with CF agreements, individually or as complex set-ups integrating several of them, are still to be assessed, especially through a theoretical lens. The following section of this paper will address the complexity of these IB set-ups around CF from a theoretical perspective.

\section{Theoretical framework}

To understand the variances in the institutional set-up of IBs, and of the two case studies in particular, three complementary theories are applied: Resource Dependence Theory (RDT), Transaction Cost Economics (TCE) and Agency Theory (AT). Although each of these theories identifies its own market frictions, focal dimensions and contractual focus, linkages between the three exist, offering multiple lenses to assess the institutional set-up of IBs and the case studies. This approach of theoretical pluralism allows a greater flexibility in our understanding of complex IB structures (Midgley, 2011).

The three theories form a hierarchy of decisions that impact the overall IB, narrowing down from identification of likely partnership to contract details (Figure 1). Firstly, RDT focuses on the external dependencies of a business and the network it operates in (Pfeffer and Salancik, 1978). IBs in general are a tool to absorb these dependencies, with CF as one particular method. IBs specifically incorporate a social aspect into their business objectives, namely the development of the contracted smallholders, hence increasing the dependence on smallholders. In effect, this mutual dependence between firm and farm serves as a starting point for the relation between the two. Secondly, TCE sheds light on the specific governance structure, once the need for a partnership has been established. According to this theory, the adopted structure aims to reduce the transaction costs between the partners (Williamson, 1979). Lastly, AT focuses specifically on the particular contract between the two parties, taking into account the difference between the delegating principal and the implementing agent (Eisenhardt, 1989b).

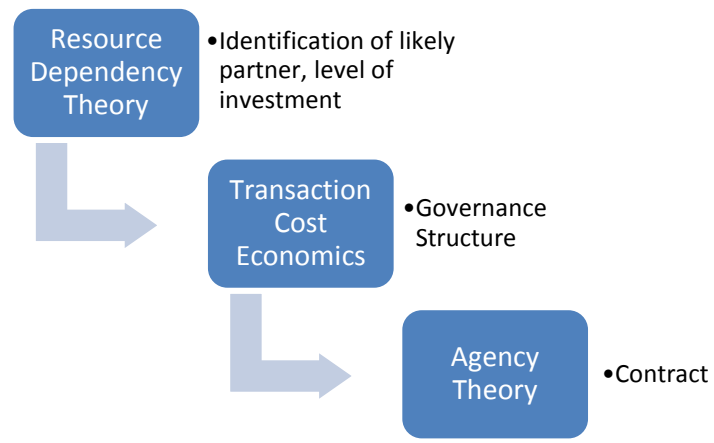

Figure 1: Hierarchy of theories explaining the organisational set-up of an IB 
Whereas these three theories all relate to the understanding of organisational structures, two elements in particular link these theories together and create an interwoven theoretical fabric: uncertainty and power imbalance. It is these two common elements that directly impact on the organisational structure, or the contractual agreement in this specific study, that is entered into between the stakeholders in an IB. This will be illustrated in the remainder of this section and is summarised in Table 1.

A first common element to the three theories is uncertainty. The central argument of the RDT is that organisations aim to reduce their dependence on their environment and consequently reduce their uncertainty to the environment (Pfeffer, 1987). Organisations are part of an interdependency network with other organisations. Where an organisation perceives uncertainty about these interdependencies as impending on its continued operation, it will attempt to manage the externalities. One of the options for externality management is engagement in hybrid partnerships, positioned between open market transactions and fully integrated hierarchic structures, with those stakeholders who have control over the external resources required by the firm (Hillman, Withers, and Collins, 2009). The aim of the firm is to gain power over resources from other parties, hence reducing the uncertainty related to these resources (Ulrich and Barney, 1984). Thus, the higher the dependence, the greater the desire for a dependent party to absorb this constraint and consequently reduce uncertainty (Casciaro \& Piskorski, 2005).

For TCE, uncertainty relates mostly to asset specificity. Uncertainties over potentially opportunistic behaviour by the partner, and over future developments, endanger partnershipspecific investments (Williamson, 1979). Due to the bounded rationality presumed in TCE, contracts cannot incorporate clauses to cover for every possible event. Thus, the partner will need safeguards other than the contract to protect its investment. Hierarchical controls serve as such a safeguard. TCE argues that more frequent transactions, together with higher asset specificity of the investment, and higher uncertainty will lead to tighter control requirements by the investing partner and thus a more hierarchical structure (Williamson, 1991).

Lastly, AT explains the contracts entered into between the cooperating parties as being dependent on the outcome uncertainty, behaviour measurability and risk aversion profiles (Eisenhardt, 1989b). The theory aims to "get the contract right" (Cook and Chaddad, 2000:210) by ex-ante alignment of the economic incentives of both the principal and the agent to draw up the most economical contract (Kim and Mahoney, 2005). The argument is that due to goal divergence, the principal is faced with moral hazard (the agent avoids its responsibilities) or adverse selection (misrepresentation of agent's capabilities). The specific contract between the principal and agent is designed to overcome this uncertainty.

Table 1: The common elements of uncertainty and power imbalance per theory and relation to level of integration

\begin{tabular}{|l|l|l|}
\hline Theory & Uncertainty & Power imbalance \\
\hline RDT & $\begin{array}{l}\text { Higher levels of mutual dependence } \\
\text { create uncertainty and drives } \\
\text { hierarchical integration }\end{array}$ & $\begin{array}{l}\text { Unequal level of dependency allows for } \\
\text { advantageous bargaining position, } \\
\text { impeding on hierarchical integration }\end{array}$ \\
\hline TCE & High frequency of transactions and & Skewed financial resources in an IB \\
\hline
\end{tabular}




\begin{tabular}{|l|l|l|l|}
\hline & $\begin{array}{l}\text { high asset specificity increase risk of } \\
\text { uncertainty and require tighter } \\
\text { control levels }\end{array}$ & $\begin{array}{l}\text { lead to high level of asset specificity } \\
\text { that are protected by safeguards biased } \\
\text { to the commercial firm }\end{array}$ \\
\hline AT & $\begin{array}{l}\text { Goal dichotomy and information } \\
\text { asymmetry between agent and } \\
\text { principal creates outcome } \\
\text { uncertainty. }\end{array}$ & $\begin{array}{l}\text { Principal in powerful position, } \\
\text { determines the contract to prevent } \\
\text { cheating by agent. }\end{array}$ \\
\hline
\end{tabular}

A second common element is that of power imbalance. Whereas the classic RDT considered the overall concept of interdependence, Casciaro and Piskorski (2005) have proposed a revision to the RDT by de-coupling this concept into power imbalance (the difference in dependence between two organisations) and mutual dependence (the sum of the dependence). Thus, two organisations can have an equal power relationship but in situations with varying degrees of mutual dependence. They argue that a higher level of power imbalance reduces the likelihood of complete constraint absorption (e.g. merger of organisations), as the more powerful organisation is unwilling to secede its advantageous bargaining position.

TCE considers hierarchical structures as a safeguard for an investing party to protect this investment. Since in an IB financial resources are generally skewed towards the commercial firm, this firm tends to commit larger funds to the partnership. Safeguards in the case of IBs, including CF projects with smallholder farmers in developing countries, are thus biased to protect the firm, rather than the farmer (Vellema, Ménard and D’Haese, 2016). It is thus likely that the outcome of the contract between partners is more beneficial to the commercial partner, compensating the risk of its investment.

This is confirmed by AT, which assumes that the principal has power over the agent and is thus able to change the agent's behaviour (Saam, 2007). To overcome agency problems, the principal can invest in behaviour-observing information systems, which come at a cost (Sharma, 1997). If information systems are not achievable, the principal is likely to enter into an outcome-based contract where the agent is remunerated based on the outcome of the agent's performance, essentially aligning the incentives between principal and agent (Eisenhardt, 1989b). However, outcome-based contracts entail a transfer of risk to the agent, who, in the basic form of this theory, is assumed to be risk averse. Especially in situations where outcome uncertainty is high, outcome-based contracts might not be attractive to the agent (Eisenhardt, 1989b). Nevertheless, AT suggests that due to the power asymmetry, it is the principal who will dictate the contract.

Power imbalance can stem from information asymmetry, which can lead to opportunistic behaviour as identified in TCE and moral hazard and adverse selection which are central to AT. Reduction of information asymmetry can lead to increased trust between the partners (Gulati and Gargiulo, 1999). Trust is considered an important element in the determination of the transaction costs (Sartorius and Kirsten, 2007) and easing of agency problems (Shapiro, 2005). Uncertainly, power and trust are all based on stakeholders' perceptions rather than objectively measurable elements. Hence, the ex-ante institutional set-up of an IB as predicted solely on the theory is likely to diverge from the actual structure which is also impacted by existing relationships and opportunities. 


\section{Case description}

Case A is located in the Limpopo province and is centred on the town of Ofcolaco, about $45 \mathrm{~km}$ west from Tzaneen. This project is sponsored by the local Supplier Development Programme (SDP) of Massmart, one of the largest distributors of consumer goods in Africa. Initially 87 farmers, organised in 24 farm units/cooperatives, were being mentored by an NGO (TechnoServe, the mentor) in the production of fresh vegetables for Massmart TechnoServe also trains the farmers in financial and marketing-related topics. Each farmer is visited by field staff once to twice a week. Since inception the number of smallholders reduced to 80 farmers in 12 collectives (Table 2).

This IB comprises three contractual arrangements each with a three year period. Firstly, a contract between Massmart and TechnoServe defines the overall functioning of the project, the financing committed by Massmart and the operational structure of a packhouse. Secondly, a contract between Massmart, TechnoServe and the smallholders covers grant financing and the loan process. The third contract is between the smallholders and the entity owning the packhouse to which produce is delivered. This contract covers the conditions of sale including the price determination and quality requirements.

Massmart has funded the refurbishment of a packhouse to fill the infrastructure and marketing gap in the area, servicing both participating and non-participating farmers. Packaged produce is marketed via a Massmart-owned wholesaler, processor and distributor of fresh fruit and vegetables. Prices paid by the packhouse to the farmer are market related but with a floor price guarantee (as calculated by TechnoServe) to protect the farmer against losses. Produce that does not meet the quality requirements is sold locally by the farmers themselves. The packhouse is owned by a non-profit company in which Massmart, TechnoServe and the farmers all have an interest. After the three-year contract, the packhouse is to be transferred to the full ownership of the farmers.

As part of the overall agreement, Massmart sets an annual target with its fruit and vegetable distributor subsidiary, stipulating the quantities it has to purchase from the Ofcolaco packhouse. The packhouse management, together with the TechnoServe staff, works out an annual production plan to meet these targets. This annual production plan is then worked out further by TechnoServe into farm unit plans. As such, TechnoServe determines which farm grows what produce and when, in order to be able to satisfy the agreed demand from Massmart. Over the year, contracted farmers all supply a variety of vegetables to the packhouse. Farmers deliver produce on a daily basis during the different crop harvesting seasons, thus engaging in a number of deliveries depending on the crop and the time of the season.

Case B is located at the Nwanedi irrigation scheme, some $60 \mathrm{~km}$ from Musina in northern Limpopo. At the request of a commercial bank which faced difficulties recovering loans provided to the local smallholders, TechnoServe became involved with mentoring these smallholders. At the same time, it recruited new farmers into its new mentorship programme. This project is sponsored by several actors, all of which are financial or development 
agencies, rather than commercial agribusinesses (but not the initiating commercial bank). TechnoServe (the mentor) firstly secures the (loan) financing, secondly disburses the loans to selected smallholders, and thirdly manages the funds on behalf of these farmers. To ensure the success of the smallholders and guarantee repayment to the lenders, the mentor is also responsible for the development of a marketing channel. As such, it has established off-take contracts for butternut with two distributors. These contracts serve as guarantees for the financial loan providers. Thus, this particular IB is largely made up of a range of contracts between TechnoServe and three financers, between TechnoServe and two offtakers and between TechnoServe and the individual smallholders (Table 2). Because the project only incorporates the production of butternut, the frequency of transactions with the offtaker is limited to the harvesting season of this crop which spans around two weeks per crop. Centrally organised collection of produce from the farmers is delivered directly to the offtaker. Over a contract period of three years, 50 individual farmers are mentored by TechnoServe, with six farmers added since inception. As in case A, TechnoServe field staff visit the farmers once to twice a week. Aside from the contracts arranged by TechnoServe, the vast majority of the mentored smallholders are engaged in a standard CF arrangement with a tomato processor. TechnoServe informally supports the tomato activities.

Table 2: Case study key dimensions

\begin{tabular}{|c|c|c|}
\hline & Case A & Case B \\
\hline $\begin{array}{l}\text { Number } \\
\text { participants }\end{array}$ & $\begin{array}{l}\text { Start: } 87 \text { farmers (24 units) } \\
\text { Current: } 80 \text { farmers (12 units) }\end{array}$ & $\begin{array}{l}\text { Start: } 44 \text { individual farmers } \\
\text { Current: } 50 \text { individual farmers }\end{array}$ \\
\hline $\begin{array}{l}\text { Predominant Land } \\
\text { ownership }\end{array}$ & $\begin{array}{l}\text { Farmer collective or individual } \\
\text { with Permission to Occupy }\end{array}$ & Individual Permission to Occupy \\
\hline Crop & $\begin{array}{l}\text { Range of fresh vegetables } \\
\text { (average } 2.9 \text { crops per farmer) }\end{array}$ & $\begin{array}{l}\text { Butternut supported by mentor; } \\
\text { Tomato supported by contractor } \\
\text { (outside IB scope) }\end{array}$ \\
\hline Contracts & $\begin{array}{l}\text {-Massmart and TechnoServe } \\
\text {-TechnoServe and smallholder } \\
\text {-Smallholder and packhouse }\end{array}$ & $\begin{array}{l}\text {-TechnoServe and offtakers } \\
\text {-TechnoServe and financers } \\
\text {-TechnoServe and smallholders } \\
\text {-External Tomato processor and } \\
\text { smallholders }\end{array}$ \\
\hline Financial support & $\begin{array}{l}\text { Revolving grant sponsored by } \\
\text { offtaker }\end{array}$ & Independent loan/grant providers \\
\hline Financing available to & All smallholders & Smallholders selected by mentor \\
\hline Packhouse & $\begin{array}{l}\text { Smallholders have collective } \\
\text { ownership in packhouse }\end{array}$ & $\begin{array}{l}\text { No formal packaging activities } \\
\text { by smallholders }\end{array}$ \\
\hline Instruments used & $\begin{array}{l}\mathrm{CF}, \quad \text { equity, mentorship, } \\
\text { collective organisation }\end{array}$ & CF, mentorship \\
\hline
\end{tabular}

The basis of both case studies is thus a form of intermediate CF (Eaton and Shepherd, 2001) where TechnoServe acts as the intermediary between the commercial firm/financer and the smallholder farmers. The firms (Massmart in Case A, wholesalers of butternut in Case B) specify the quality and quantity of produce required, but transfer responsibility of implementing these contract specifics to the external mentor. As such, the intermediary provides a dual role: firstly that of central agent allowing the offtaker to interact with one partner rather than multiple smallholders, and secondly that of extension officer providing 
both technical and financial knowledge to the smallholders to ensure they can and do adhere to the standards specified in the contract.

\section{Rationalising the organisational structure}

This section aims to explain the different organisational structures observed in the two case studies. For this, it applies elements from the above-detailed Resource Dependence Theory, Transaction Costs Economics, and Agency Theory - particularly through their uncertainty and power imbalance aspects.

\section{Resource Dependence Theory}

Resource Dependence Theory's starting argument is that organisations are dependent on their environment. The organisation aims to reduce the uncertainty related to these dependencies, leading the organisation to endeavour to attain a position of power over external resources by entering into inter-organisational networks (Pfeffer and Salancik, 1978). The level of mutual dependence between the firm and the farmer is high in Case A. Political requirements force Massmart to integrate local suppliers into its supply chain. Thus, the company depends on smallholder farmers to supply part of its produce. The farmers, on the other hand, lack the resources to enter into the large commercial value chain and thus rely on the financing and market offered by the firm and the knowledge of the mentor. Massmart does have access to a large pool of alternative smallholders, whereas potential offtakers for the smallholders are limited . As a result, Massmart has a more powerful position in the partnership than the smallholders. This mutual dependence is absent in Case B where the offtaker has multiple sources of supply besides the Nwanedi smallholders. The Nwanedi farmers, on the other hand, are dependent on the financing, knowledge and market offered through the intermediary partner TechnoServe, but have alternative sources in the form of a tomato processor and other (government and NGO) training bodies operating in the area. The higher degree of dependency of the offtaker on the farmers in Case A might thus be a driver for the firm to invest more in this relationship in order to reduce uncertainty, obtain a higher degree of power over the produce, and work closer with these smallholders, resulting in additional links to be established beyond the supply contract compared with the situation of Case B.

Firstly, willingness by the offtaker to invest is illustrated by the packaging requirements in both case studies. The mentor and firm identified a lack of packaging facilities for fresh vegetables in both project areas. In Case B, the lack of packing infrastructure resulted in the choice of a (low value) crop that can be packed without such a facility. The firm's higher dependence on the smallholders in Case A meant that the offtaker had to present a higher value proposition to the smallholders to attract them into the scheme. At inception of this project, packaging occurred at a privately owned facility, but the participating smallholders who incurred these costs perceived the prices as being unfair. In an attempt to reduce dependence on outside stakeholders that were not trusted by the farmers, and to bring down packaging-related costs, the firm opted for the establishment of a separate packhouse.

Secondly, investments by the firm differ between the two cases in the area of smallholder financing. The smallholders in Case A all have access to full financing through an offtaker sponsored revolving grant fund. This fund enables the smallholders to engage in the activities 
required by the offtaker. The offtakers in Case B, who are not dependent on the smallholders, do not feel the need to support these small suppliers. Hence, the mentor has had to engage independent financers who are not able to fully fund all the mentored farmers.

Thus, Resource Dependence Theory reasoning can be regarded as underlying the institutional boundaries of the two cases. High dependency by the firm in Case A has triggered the establishment of a more integrated structure, allowing the firm to gain a higher degree of control over the upstream activities on which it depends. Whereas in Case A the dependency is highest on the side of the offtaker, in Case B the smallholders have a higher dependency on the offtaker. The fact that Case A shows a higher degree of vertical integration can be explained by the dominance of the commercial partner compared to the smallholder. But, whereas Resource Dependency Theory can describe the origin and degree of cooperation, it is insufficient to explain the governance structure of the alliance. For this, we turn to Transaction Cost Economics, and specifically the concepts of asset specificity and transaction frequency.

\section{Transaction Cost Economics}

According to TCE, uncertainty regarding transaction costs results from asset specificity and the related appropriation concerns. Transaction-specific investments require the firm to safeguard this investment and thus maintain a level of control, encouraging more hierarchical partnerships (Williamson, 1991). The appropriation concerns are therefore more pertinent to the financing partner providing the funding to operate the project. Funding for inputs and training is fully supplied by the offtaker to all contracted smallholders in Case A, but only partially in Case B by external funders. Furthermore, Case A has additional investment funded by the offtaker in the packaging facility.

Input funding is implemented differently between the two case studies. A revolving grant funded by the firm allows interest-free loans to all farmers in Case A. Whereas a small number of contracted farmers in Case B have access to a similar grant structure, other farmers rely on interest-bearing loans provided by external funders or do not receive any financial support at all. As a result of the different funding structures, safeguard mechanisms differ between the two cases. In Case A, three mechanisms are at work. Firstly, the fund is in the collective interest of all farmers: non-recovery impacts on the overall fund availability for other farmers. One of the funds in Case B equally relies on this mechanism, but is limited to those smallholders who have been selected by the mentor. Secondly, non-repayment leads to the immediate termination of the relationship between the smallholder and TechnoServe, and thus the smallholder loses both the mentorship and access to the Massmart marketing channel. Contract termination thus serves as an incentive for the farmers to adhere to the agreement. The third safeguard for the firm lies in the central management of the fund with TechnoServe. Through its close relationship with the smallholders and the high field presence, the mentor organisation is in a strong position to monitor the farmers' activities. The mentor furthermore administers all the financial flows and thus can deduct a loan repayment from a farmer's crop income. This third safeguard, central administration of the finances by the mentor, also applies to the financial sponsors of Case B, both for the interest free and interest bearing funding. The external funder providing interest-bearing loans has 
implemented the general safeguard of interest rates needed to be paid by the individual smallholder (and administered by the mentor).

The second investment by the firm in Case A is the refurbishment of a packhouse. This packhouse is considered to be essential for filling the existing infrastructure gap in the area. Without this facility, the production of several of the vegetable types would be less viable, and the offtaker would be at a higher risk of extra-contractual sales. Furthermore, it allows for additional job creation in the area, thus contributing to the community in general and improving the social image of the project. As such, the packhouse serves as a safeguard for the supply contract, by creating an enabling environment. This facility illustrates the aspect of asset specificity, which is regarded as a critical determinant for organisational structure by Williamson because it "creates bilateral dependency and poses added contracting hazards" (Williamson, 1991: 282). He argues that a higher asset specificity of a firm in a partnership environment is likely to result in higher hierarchical control for better managing anticipated uncertainty over the use of this asset, although this higher level of control comes at higher coordination costs. In this view, it can be argued that the asset specificity in Case A has triggered the funding firm to enter into a hybrid structure of co-ownership of the packhouse, including the smallholders and the mentor as co-owners. Whereas this increases the coordination costs for the firm (in this particular situation the firm has seconded a staff member to manage the packhouse activities), it does give the firm a larger degree of control without fully integrating this entity into its own hierarchy.

Anticipation of appropriation costs prompts firms to select a reliable partner (Dekker, 2004). As Gulati and Gargiulo (1999) argue, firms rely on prior alliances in building their networks. TechnoServe is an organisation known to Walmart, the parent firm of Massmart, and as an NGO, it has an established track record globally. The firm thus has grounds to trust the mentor, reducing appropriation cost concerns on the part of the mentor and the farmers. This trust does not extend to the relationship between TechnoServe and smallholders.

Aside from the asset specificity, frequency of transactions is important to the offtaker as single party dealing with multiple suppliers. Individual transactions with each of the contracted farmers incur higher transaction costs than dealing with a single transaction partner, in this case the mentor. Engaging a central contact point to firstly identify potential smallholders and secondly to coordinate the implementation of the contract reduces the number of transactions the firm/financer has to engage in. But, this argument holds for both the offtaker and the implementing agent. Thus, the mentor itself will aim for a similar reduction of transaction and coordination costs. This is more pressing in Case A where the required supply quantities are not only larger, but also include a range of produce, versus the single crop in Case B. Deliveries in case A, initiated by the farmer, take place on a daily basis, for a period of 12 weeks. The delivery period in case B spans roughly two weeks and collection from individual farmers is centrally coordinated by the mentor. The farmer collectives in the more complex Case A allow the mentor to more efficiently coordinate activities over a large number of smallholders. Combining farmer collectives with supply contract arrangements is a well-established method that is applied in multiple sectors around the world (e.g. Runsten, 1994). 
Transaction costs are also higher in a situation where the contracted farmers are unfamiliar with the contracted crop. This requires additional resources from the offtaker to ensure the smallholders are trained and assisted to grow the produce according to the specification of the offtaker. The firm can choose between internally employed extension officers (often the case where the offtaker is a processing company specialised in a few crops) or external agricultural specialists (where the firm, such as a retailing offtaker, has no specific crop knowledge). In both Cases A and B, the offtakers fall into the second category, hence their choice to work through an implementing agent, TechnoServe.

\section{Agency Theory}

We have illustrated that from a TCE perspective, the inclusion of an intermediary partner is a way of reducing the transaction costs for the firm. Nevertheless, this function can also be performed by, for example, a farmers' collective. The question remains, why did the firm opt for an external agent to coordinate the contract implementation? This question can partly be explained by the Agency Theory which concentrates, among other things, on outcome uncertainty driven by goal dichotomy and the role of information asymmetry. The reasoning is that the principal in the partnership (i.e. the contracting firm) does not have certainty about the agent's (i.e. the smallholder) behaviour. To ensure the contract is adhered to and the outcomes of the contract are positive for the principal, the firm aims to implement measures to increase the information on agent behaviour and thus reduce moral hazard on the part of the agent (Eisenhardt, 1989b).

These aspects coalesce to prompt the firm to rely on a trusted external partner, rather than for example a farmers' collective, to firstly implement an information system allowing for the reduction of unobservable behaviour by the agent, whilst simultaneously aligning the goals of the agent and the external intermediary. TechnoServe, an organisation that Massmart works with across the globe, is in charge of drawing up production plans, input requirement determination and the like, as well as observing the implementation of these plans, thus reducing the flexibility of the smallholders to engage in non-contractual behaviour. In Case A, the offtaker (partly) finances the activities of the mentor, making TechnoServe contractually dependent on the offtaker, in turn incentivising the mentor to implement the contract with the individual smallholders. The mentor is responsible for the full harvest of the smallholders, including sub-standard produce for which it needs to find marketing channels. To reduce the additional costs related to alternative market development, the mentor will aim for the smallholders to produce high quality crops, thus aligning its goals to that of the firm but also positioning itself closer to the farmer as it has a broader mandate than just the contracted crop. This argument holds for both Cases A and B but due to the higher value and volume and larger range of crops in Case A, this argument holds more weight in Case A than in Case B. Goal congruence between all three parties in Case A is further achieved by shared ownership in the packhouse. The value adding activities in the packhouse serve as incentive since an increase in packhouse activities increases the value of their collectively owned asset. Lastly, contract termination serves as the ultimate incentive for smallholders to adhere to the contractual agreements. 
Nevertheless, in Case A, where smallholders have access to alternative markets, absence of trust between the mentor and the offtaker on the one hand and the smallholders on the other hand, has resulted in high levels of extra-contractual sales despite the structure designed by the offtaker and mentor. Lack of trust flows from a lack of insight in the working of the project (information asymmetry) and thus the envisaged benefits for the smallholders. Rather than receiving delayed payment at unknown price, the farmers opt for immediate cash receipt from external traders. This has led the firm to adjust the remuneration system to be more favourable for the smallholders.

In summary, increased dependence of offtaker on the smallholders drives this offtaker to strive for more vertical integration and higher investment by the offtaker in Case A (RDT). As a result, the asset specificity in Case A is higher, requiring more safeguards for the investors, including shared ownership in the packhouse asset. Furthermore, the more complex offtake agreement requires collective organisation to manage the smallholders efficiently and a mentor that can assist smallholders with unknown crops (TCE). An external implementing agent allows for monitoring of farmer behaviour (AT). Table 3 presents a summary of the case studies within the theoretical framework presented.

Table 3: Application of theoretical framework to case studies - structural differences in institutional set-up explained

\begin{tabular}{|c|c|c|c|}
\hline Theory & Concern & Case A & Case B \\
\hline \multirow[t]{2}{*}{ RDT } & Uncertainty & $\begin{array}{l}\text { - High mutual dependence drives firm } \\
\text { to invest in farmers (packhouse and } \\
\text { revolving grant fund) and in external } \\
\text { implementing agent (mentor) for } \\
\text { high value crops. }\end{array}$ & $\begin{array}{l}\text { - Low mutual dependence } \\
\text { requires simple crop plan with } \\
\text { low investment needs. }\end{array}$ \\
\hline & $\begin{array}{l}\text { Power } \\
\text { imbalance }\end{array}$ & $\begin{array}{l}\text { - Firm finances implementing agent } \\
\text { and farmers, thus highly imbalanced } \\
\text { relationship favouring firm in } \\
\text { decision making processes. }\end{array}$ & $\begin{array}{l}\text { - External financing balances } \\
\text { power between firm, farm and } \\
\text { implementing agent resulting in } \\
\text { less vertical integration }\end{array}$ \\
\hline \multirow[t]{2}{*}{ TCE } & Uncertainty & $\begin{array}{l}\text { - Complex cropping plan leads to } \\
\text { higher frequency of transaction. } \\
\text { Centralised administration and } \\
\text { farmer's collective reduce the } \\
\text { transaction costs for the firm. }\end{array}$ & $\begin{array}{l}\text { - Centrally planned collection } \\
\text { overcomes } \\
\text { challenges related to transport } \\
\text { and minimises transactions } \\
\text { between smallholders and } \\
\text { offtakers }\end{array}$ \\
\hline & $\begin{array}{l}\text { Power } \\
\text { imbalance }\end{array}$ & $\begin{array}{l}\text { - Investments safeguarded by fixed } \\
\text { supply contract (offtaker, packhouse, } \\
\text { smallholders) and loan fund } \\
\text { administration by mentor }\end{array}$ & $\begin{array}{l}\text { - No safeguards needed in } \\
\text { absence of low transaction } \\
\text { frequency and asset specificity }\end{array}$ \\
\hline $\mathrm{AT}$ & Uncertainty & $\begin{array}{l}\text { - Moral hazard managed through } \\
\text { contractual engagement of external } \\
\text { implementing agent to select and } \\
\text { monitor farmers, and to implement } \\
\text { crop plan. } \\
\text { - Shared ownership in packhouse to } \\
\text { align goals for smallholders with }\end{array}$ & $\begin{array}{l}\text { - Goal divergence and moral } \\
\text { hazard limited due to low } \\
\text { mutual dependency }\end{array}$ \\
\hline
\end{tabular}




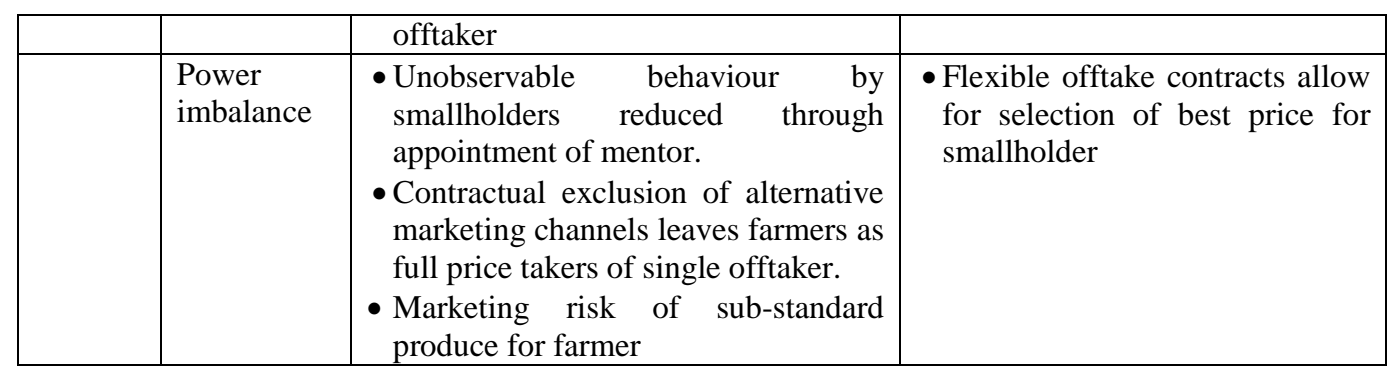

\section{Conclusion}

The comparison of the two case studies in this paper presents evidence that the combination of Resource Dependence Theory, Transaction Costs Economics and Agency Theory provides a framework detailing the differences that emerge in complex IBs that apply CF as one of multiple tools to include smallholders farmers in the commercial agriculture value chain. The starting point of the level of mutual dependency of the RDT, combined with the power asymmetry between the partners, explains the organisational boundaries within which the CF operates. A higher level of dependency, especially by the more powerful firm, will stimulate the firm to control more of this dependency, hence a higher level of vertical integration with the contracted farmers and a higher level of investment. In this study, RDT explains the difference in crop selection and the inclusion of a packhouse, financed by the firm. TCE then foresees that, due to the higher investments made by the firm in the higher dependency project, the increased asset specificity leads the firm to share ownership in the downstream value adding activity. Safeguards are further required to protect the financing provided to the contracted smallholders. Collective organisation not only renders the contracted farmers mutually responsible and dependent on each other, it also allows a more efficient implementation of the more complex production scheme. Lastly, the usage of a known and trusted external mentor allows an amelioration of the moral hazard challenge identified in AT and aligns the goals of the firm, the farm and the implementing agent.

Although the findings of this paper are based on only two cases, the provisional conclusion is that IBs incorporating CF agreements as part of a complex structure have the potential to increase the level of control by the firm in an efficient manner. Complex CF constructions are likely in cases where the offtaker firm is highly dependent on a large number of small-scale farmers who are new to the contracted crop. Whereas this can be advantageous to the firm, it potentially leaves the smallholders in an unclear position, where they lose sight of the workings of the contract, their risks and their rewards (Chamberlain and Anseeuw, Forthcoming). As such, it questions the degree of inclusiveness for the smallholder farmers of these complex IBs. Conversely, IBs can overcome existing power disparities, as exposure to the commercial value chain does reduce the initial information asymmetry. Generally, IBs are a contingent relationship, developing and adjusting their structures overtime. Further research into IBs with different structures and stakeholders is required to ascertain the validity of the proposed theory and outcomes. 


\section{Bibliography}

Allen, D. and Lueck, D. 1992. Contract Choice in Modern Agriculture: Cash Rent Versus Crop Share. The Journal of Law and Economics 35(2): 397-426.

Barrett, C. B., Bachke, M. E., Bellemare, M. F., Michelson, H. C., Narayanan, S. and Walker, T. F. 2012. Smallholder Participation in Contract Farming: Comparative Evidence from Five Countries. World Development 40(4):715-730.

Baumann, P. 2000. Equity and efficiency in contract farming schemes: The experience of agricultural tree crops. Working Paper 139. London: Overseas Development Institute.

Bellemare, M. F. 2012. As You Sow, So Shall You Reap: The Welfare Impacts of Contract Farming. World Development 40(7):1418-1434.

Bijman, J. 2008. Contract farming in developing countries. An overview. Wageningen: Wageningen University.

Bolwig, S., Gibbon, P. \& Jones, S. 2009. The Economics of Smallholder Organic Farming in Tropical Africa. World Development 37(6):1094-1104.

Casciaro, T. and Piskorski, M. J. 2005. Power Imbalance, Mutual Dependence, and Constraint Absorption: A Closer Look at Resource Dependency Theory. Administrative Science Quarterly 50(2):167-199.

Chamberlain, W. \& Anseeuw, W. 2015. Institutional Set-ups. Inclusive Businesses in Agriculture. Presented at the Governance Innovation Week, 1-6 June 2015, University of Pretoria, Pretoria.

Chamberlain, W. \& Anseeuw, W. 2016. The scalability potential of Inclusive Business in agriculture: Can bigger be better and for whom? Paper presented at the $17^{\text {th }}$ Land and Poverty Conference, 14-18 March 2016, World Bank, Washington D.C.

Chamberlain, W. \& Anseeuw, W. Forthcoming. Inclusive Businesses in South African agriculture. Stellenbosch: Sun Metro.

Clapp, R.A.J. 1988. Representing Reciprocity, Reproducing Domination: Ideology and the Labour Process in Latin American Contract Farming. The Journal of Peasant Studies 16(1):5-39.

Clemente, F. and da Silva Júnior, A. G. 2013. Contracts Between Small Scale Soybean Farmers and the Biodiesel Industry in Brazil: An Application of Principal-Agent Model. Paper presented at the $6^{\text {th }}$ International European Forum on System Dynamics and Innovation in Food Networks, 18-22 February 2013, Innsbruck-Igls, Austria. 
Cook, M. L. and Chaddad, F. R. 2000. Agroindustrialization of the global agrifood economy: bridging development economics and agribusiness research. Agricultural Economics 23:207-218.

Coulter, J., Goodland, A., Tallontire, A. and Stringfellow, R. 1999. Marrying farmer cooperation and contract farming: provision in a liberalising sub-Saharan Africa. Natural Resource Perspectives 48. London: ODI.

da Silva, C.A. 2005. The growing role of contract farming in agri-food systems development: Drivers, theory and practice. Rome: FAO.

da Silva, C. A. and Rankin, M. 2013. Contract farming for inclusive market access. Rome: FAO.

de Koning, M. and de Steenhuijsen Piters, B. 2009. Farmers as shareholders. A close look at recent experience. Bulletin 390. Amsterdam: KIT Publishers.

Dekker, H. C. 2004. Control of inter-organizational relationships: evidence on appropriation concerns and coordination requirements. Accounting, Organizations and Society 29:27-49.

Dileep, B.K., Grover, R.K. and Rai, K.N. 2002. Contract Farming in Tomato: An Economic Analysis. Indian Journal of Agricultural Economics 57(2):197-210.

Eaton, C. and Shepherd, A. W. 2001. Contract Farming. Partnerships for growth. Bulletin 145. Rome: FAO Agricultural Services.

Eisenhardt, K.M. 1989a. Building Theories from Case Study Research. The Academy of Management Review 14(4):532-550

Eisenhardt, K. M. 1989b. Agency Theory: An Assessment and Review. Academy of Management Review 14(1):57-74.

Glover, D.J. 1987. Increasing the Benefits to Smallholders from Contract Farming: Problems for Farmers’ Organizations and Policy Makers. World Development 15(4): 441-448.

Gulati, R. and Gargiulo, M. 1999. Where do Interorganizational Networks come from? The American Journal of Sociology 104(5):1439-1493.

Guo, H., Jolly, R.W. and Zhu, J. 2005, April. Contract farming in China: Supply chain or ball and chain. In $15^{\text {th }}$ Annual World Food \& Agribusiness Symposium, IAMA, Chicago.

Hillman, A. J., Withers, M. C. and Collins, B. J. 2009. Resource dependence theory: A review. Journal of Management 35(6): 1404-1427.

Kim, J. and Mahoney, J. T. 2005. Property rights theory, transaction costs theory, and agency theory: An organizational economics approach to strategic management. Managerial and Decision Economics 26:223-242. 
Kirsten, J. and Sartorius, K. 2002. Linking agribusiness and small-scale farmers in developing countries: Is there a new role for contract farming? Development Southern Africa 17(4):503-529.

Kirsten, J. and Sartorius, K. 2007. A framework to facilitate institutional arrangements for smallholder supply in developing countries: An agribusiness perspective. Food Policy 32:640-655.

Levin, R. 1987. Contract farming in Swaziland: Peasant differentiation and the constraints of land tenure. Paper presented at the African Studies Seminar, August 1987, University of the Witwatersrand, Johannesburg.

Midgley, G. 2011. Theoretical Pluralism in Systemetic Action Research. Systemetic Practice and Action Research 24(1):1-15

Miyata, S., Minot, N. and Hu, D. 2009. Impact of Contract Farming on Income: Linking Small Farmers, Packers, and Supermarkets in China. World Development 37(11):1781-1790).

Nagaraj, N., Chandrakanth, M.G., Chengappa, P.G., Roopa, H.S. \& Chandakavate, P.M. 2008. Contract Farming and its Implications for Input-supply, Linkages between Markets and Farmers in Karnataka. Agricultural Economics Research Review 21 (conference number):307-316.

Oya, C. 2012. Contract Farming in Sub-Saharan Africa: A Survey of Approaches, Debates and Issues. Journal of Agrarian Change 12(1):1-33.

Pfeffer, J. 1987. A resource dependence perspective on interorganizational relations. In M. S. Mizruchi, \& M. Schwartz, Intercorporate relations: The structural analysis of business (pp. 22-55). Cambridge: Cambridge University Press.

Pfeffer, J. and Salancik, G. R. 1978. The external control of organizations: A resource dependence perspective. New York: Harper \& Row.

Prowse, M. 2007. Making contract farming work with co-operatives. London: Overseas Development Institute.

Prowse, M. 2012. Contract Farming in Developing Countries - A Review. A Savoir (No12). Paris: Agence Française de Développement.

Rösler, U., Hollmann, D., Naguib, J., Oppermann, A. \& Rosendahl, C. 2013 Inclusive business models. Options for support through PSD programmes. Bonn: GIZ.

Runsten, D. 1994. Transaction costs in Mexican Fruit and Vegetable Contracting: Implications for Asociación en participación. Paper presented at the XVIII International Congress of the Latin American Studies Association, 10-12 March 1994, Atlanta. 
Saavedra, Y. 2014. Mozambique - DADTCO. In M. E. Sopov. Is Inclusive Business for you? (pp. 69-78). Wageningen: Centre for Development Innovation.

Sartorius , K. and Kirsten, J. 2007. A framework to facilitate institutional arrangements for smallholder supply in developing countries: An agribusiness perspective. Food Policy 32(5-6):640-655Shapiro, S. P. 2005. Agency Theory. Annual Review of Sociology 31:263-284.

Sharma, A. 1997. Professional as Agent: Knowledge Asymmetry in Agency Exchange. The Academy of Management Review 22(3):758-798

Simmons, P. 2002. Overview of smallholder contract farming in developing countries. Rome, FAO.

Simmons, P., Winters, P. and Patrick, I. 2005. An Analysis of Contract Farming in East Java, Bali and Lombok, Indonesia. Agricultural Economics 33(supplement):513-525.

Singh, S. 2002. "Contracting Out Solutions: Political Economy of Contract Farming in the Indian Punjab”. World Development, 30(9):1621-1638.

Strohm, K. and Hoeffler, H. 2006. Contract farming in Kenya: Theory, evidence from selected value chains, and implications for development cooperation. Nairobi: PSDA, GIZ.

Ulrich, D. and Barney, J. B. 1984. Perspectives in organizations: Resource dependence, efficiency, and population. Academy of Management Review 9:471-481.

Vavra, P. 2009. "Role, Usage and Motivation for Contracting in Agriculture”. OECD Food, Agriculture and Fisheries Papers, No.16. OECD Publishing. http://dx.doi.org/10.1787/225036745705

Vellema, S. 2002. Making contract farming work? Society and technology in Philippine transnational agribusiness. PhD Thesis Wageningen Universiteit.

Vellema, W., Ménard, C. \& D'Haese, M. 2016. How firm investment and appropriability hazard shape governance structure. Paper presented at the World Bank Conference on Land and Poverty 2016, 14-18 March 2016, Washington D.C.

Watts, M. 1992. Peasants and Flexible Accumulation in the Third World: Producing under Contract. Economic and Political Weekly 27(30):PE90-PE97.

Williamson, O. E. 1979. Transaction-Cost Economics: The Governance of Contractual Relations. Journal of Law and Economics 22(2):233-261.

Williamson, O. E. 1991. Comparative economic organization: The analysis of discrete structural alternatives. Administrative Science Quarterly 36(2):269-296.

Yin, R. 1984. Case study research. Beverly Hills CA: Sage Publication 